\title{
PURIFICATION AND IMMUNOLOGICAL CHARACTERIZATION OF A CALCIUM PUMP FROM BOVINE BRAIN SYNAPTOSOMAL VESICLES ${ }^{1}$
}

\author{
SHEW Y. CHAN, ${ }^{*}$ EMMA JEAN HESS, ${ }^{*}$ HANNAH RAHAMIMOFF, $\ddagger$ AND STANLEY M. GOLDIN*,2 \\ * Department of Pharmacology, Harvard Medical School, Boston, Massachusetts 02115 and $\$$ Department of Biochemistry, \\ Hadassah Medical School, Hebrew University, Jerusalem, Israel
}

Received September 22, 1983; Revised December 7, 1983; Accepted December 13, 1983

\begin{abstract}
In previous work (Papazian, D., H. Rahamimoff, and S. M. Goldin (1979) Proc. Natl. Acad. Sci. U. S. A. 76: 3708-3712), an ATP-dependent calcium transport activity derived from rat brain synaptosomes was reconstituted into artificial lipid vesicles and substantially purified by transportspecific fractionation. When this procedure was applied to bovine brain synaptosomes, the $\sim 70$ fold purified, reconstituted $\mathrm{Ca}^{2+}$ uptake system contained two major polypeptides of $M_{\mathrm{r}}=230,000$ ("C230") and 94,000 ("C94") as observed on sodium dodecyl sulfate (SDS) gels. Evidence is presented here that these polypeptides are immunologically related to one another and that the synaptosomal $\mathrm{Ca}^{2+}$ pump is immunologically distinct from $\mathrm{Ca}^{2+}$ pumps in non-neuronal cells.

Antisera and monoclonal antibodies to the purified, reconstituted protein did not significantly cross-react with the $\mathrm{Ca}^{2+}$ pumps or any other components of bovine sarcoplasmic reticulum or erythrocytes. However, these antibodies did cross-react with a component of bovine brain axolemmaenriched membranes. A monoclonal antibody was produced that immunoprecipitated the $\mathrm{Ca}^{2+}$ transport activity, both in native, synaptosomal vesicles and in liposomes containing the reconstituted transport system. This antibody bound C230 more prominently than C94 on Western blots of SDS gels. An antiserum raised against C94 alone, obtained by elution from SDS gels, was also found to bind most prominently to C230 on Western blots.

These results suggest that this synaptosomal $\mathrm{Ca}^{2+}$ pump is specific to nerve tissue and that $\mathrm{C} 94$ and $\mathrm{C} 230$ are structurally homologous components of this transport activity.
\end{abstract}

The primary event that initiates the release of neurotransmitter from nerve terminals is the influx of $\mathrm{Ca}^{2+}$. The termination of the release of neurotransmitter requires the removal of $\mathrm{Ca}^{2+}$ from the cytoplasm of the nerve terminal (reviewed by Reichardt and Kelly, 1983). This can be accomplished by extrusion of $\mathrm{Ca}^{2+}$ from the neuron via $\mathrm{Na}^{+} / \mathrm{Ca}^{2+}$ exchange (Rahamimoff and Spanier, 1979; Gill et al., 1981; Michaelis and Michaelis, 1981) or by ATP-driven active transport (Gill et al., 1981). Cytoplasmic $\mathrm{Ca}^{2+}$ levels can also be reduced by seques-

\footnotetext{
${ }^{1}$ This work was supported by grants to S. M. G. from the United States Public Health Service (NS 16475), the McKnight Foundation, and the Searle Scholars Program; and by a United States Israeli Binational Science Foundation Grant to H. R. S. Y. C. was a Pharmaceutical Manufacturer's Association Postdoctoral Fellow. We are grateful to Diane Papazian, Kathy Puckett, and Kathleen Sweadner for careful reading of the manuscript. Colin Barnstable of the Neurobiology Department, Harvard Medical School, provided invaluable guidance in the production of monoclonal antibodies.

${ }^{2}$ To whom correspondence should be addressed.
}

tration of $\mathrm{Ca}^{2+}$ into vesicles within the nerve terminals (Blaustein et al., 1978a, b; Rahamimoff and Abramovitz, 1978a, b) and into mitochondria (Bygrave, 1977). Our understanding of the molecular mechanism and the regulation of neurotransmitter release could be aided by the purification, characterization, and eventual immunocytochemical localization of the transport proteins that regulate intraterminal $\mathrm{Ca}^{2+}$ levels.

We have previously reported the development of a new approach ("transport specific fractionation") for purifying membrane transport proteins (Goldin and Rhoden, 1978). This technique was used in the following way for the purification of an ATP-dependent calcium transport component (Papazian et al., 1979) from a vesicle fraction derived from rat brain synaptosomes (Rahamimoff and Abramovitz, 1978a). The membrane proteins of the crude vesicle fraction were dissolved in detergent in the presence of a large excess of exogenous phospholipid. Upon removal of detergent, these proteins were randomly distributed into small artificial lipid vesicles ("liposomes"). 
This results in the incorporation of, on the average, only one or a few membrane proteins into the membrane of each liposome. Proteins responsible for ATP-dependent $\mathrm{Ca}^{2+}$ uptake reconstituted into a small fraction of these liposomes. The density of only those liposomes containing this uptake activity was increased by ATP-dependent accumulation of calcium oxalate, enabling the reconstituted transport activity to be purified approximately 100 fold on density gradients.

This purified $\mathrm{Ca}^{2+}$ transport activity from rat brain, as visualized on SDS gels, contained three major polypeptides of $M_{\mathrm{r}}=\sim 230,000,140,000$, and 94,000 ("C230," "C140," and "C94," respectively). A question of interest is the relationship of these polypeptides to one another. Are they subunits of a single $\mathrm{Ca}^{2+}$ pump, or do they comprise more than one $\mathrm{Ca}^{2+}$ transport system? A calmodulin-stimulated $\mathrm{Ca}^{2+}$ pump from the plasma membrane fraction of rat brain synaptosomes has recently been purified by calmodulin affinity chromatography (Hakim et al., 1982; Papazian et al., 1982, 1984); this pump corresponds in molecular weight to C140. Antibodies to the erythrocyte calmodulin-stimulated $\mathrm{Ca}^{2+}$ pump cross-react with this protein (Hakim et al., 1982). The aim of this study is to determine the functional significance of C94 and C230. We report here that ATPdependent calcium transport activity purified from bovine brain synaptosomal vesicles by transport specific fractionation comprises primarily $\mathrm{C} 94$ and $\mathrm{C} 230$. Antisera and monoclonal antibodies raised against these proteins do not cross-react with the $\mathrm{Ca}^{2+}$ pumps of either erythrocytes or sarcoplasmic reticulum. A monoclonal antibody was obtained that can immunoprecipitate the reconstituted $\mathrm{Ca}^{2+}$ uptake activity and specifically interacts with these two polypeptides.

\section{Materials and Methods}

Reconstitution and purification of synaptosomal vesicle $\mathrm{Ca}^{2+}$ pump. The "synaptosomal vesicle" fraction was prepared from bovine brain by the procedure originally described for rat brain by Rahamimoff and Abramovitz (1978a). Calf cerebral cortex, obtained from a local slaughterhouse, was chilled to $0^{\circ} \mathrm{C}$ within 10 to $15 \mathrm{~min}$ after the animal was slaughtered. Each preparation employed 150 to $200 \mathrm{gm}$ of tissue. The yield of the synaptosomal vesicle fraction was typically $1 \mathrm{mg}$ of protein/ gm of wet weight of tissue. The vesicle fraction was frozen in liquid nitrogen and stored at $-70^{\circ} \mathrm{C}$.

The reconstitution procedure is a scaled up version of that of Papazian et al. (1979), with the following modifications. Bovine rather than rat synaptosomal vesicle fractions were used. The cholate solublized synaptosomal vesicle/soybean phospholipid mixture $(50 \mathrm{ml})$ was dialyzed for $15 \mathrm{hr}$ against 4 liters of $300 \mathrm{~mm}$ potassium oxalate, $5 \mathrm{~mm}$ 2-mercaptoethanol, $\mathrm{pH} 7.8$, using a hollow fiber "artificial kidney" unit (Cordis Dow CDAK 0.6D) in the same configuration previously employed for the smaller scale BioRad hollow fiber dialysis unit (Goldin, 1977). The liposomes formed were then dialyzed against 1.5 liters of $5 \mathrm{~mm}$ potassium oxalate, $5 \mathrm{~mm} 2$-mercaptoethanol, $700 \mathrm{~mm}$ glycerol, $25 \mathrm{~mm} \mathrm{KCl}, 50 \mathrm{~mm}$ Tris, 25 $\mathrm{mM}$ ammonium acetate, $\mathrm{pH} 7.5$, for $2 \mathrm{hr}$.

The gradient centrifugation procedure employed $8 \mathrm{ml}$ of reconstituted liposomes per gradient tube in the first gradient. Gradients were formed from $16 \mathrm{ml}$ of heavy phase $\left(5 \mathrm{mM} \mathrm{K}_{2}\right.$ oxalate, $700 \mathrm{mM}$ sucrose, $50 \mathrm{mM} \mathrm{KCl}$, $50 \mathrm{~mm}$ Tris, $5 \mathrm{mM} \mathrm{2-mercaptoethanol,} \mathrm{pH} 7.5)$ and 14 $\mathrm{ml}$ of light phase $\left(5 \mathrm{mM} \mathrm{K}_{2}\right.$ oxalate, $700 \mathrm{~mm}$ glycerol, 50 $\mathrm{mm} \mathrm{KCl}, 50 \mathrm{~mm}$ Tris, $5 \mathrm{~mm} 2$-mercaptoethanol, $\mathrm{pH} 7.5$ ) solutions, over a $2-\mathrm{ml} 65 \%$ sucrose cushion. The solutions for both the first and second gradients contained $25 \mathrm{~mm}$ ammonium acetate and $25 \mathrm{mM} \mathrm{KCl}$. Normally six Beckman VTI50 gradient tubes were used simultaneously, enabling $48 \mathrm{ml}$ of reconstituted liposomes to be processed. The lipid vesicle peak from the first gradient was incubated for $20 \mathrm{~min}$ with $0.1 \mathrm{mM}{ }^{45} \mathrm{CaCl}_{2}\left(10^{5} \mathrm{cpm} /\right.$ $\mathrm{nmol}$ ), $5.5 \mathrm{mM} \mathrm{MgCl}$, $2 \mathrm{mM} \mathrm{MgATP}$, before being diluted and placed on the second gradient. Twenty microliters of each 1-ml fraction from the second gradient were counted on a liquid scintillation counter. The peak (or shoulder) of ${ }^{45} \mathrm{CaCl}_{2}$ below the main lipid vesicle peak, as described under "Results" contained the purified, reconstituted liposomes. These fractions were pooled and stored at $-70^{\circ} \mathrm{C}$. The purification procedure was in other respects identical to that previously described.

For use in gel electrophoresis and immunization, the purified material was dialyzed in EDTA/ $\mathrm{Na}_{2} \mathrm{CO}_{3}$ pretreated Spectra no. 2 dialysis tubing for $16 \mathrm{hr}$ against two 2-liter batches of $1 \mathrm{~mm}$ Tris, $\mathrm{pH}$ 7.4. The material was then concentrated to $25 \mathrm{ml}$ by lyophilization and centrifuged at 45,000 rpm for $3 \mathrm{hr}$ in a Beckman $50.2 \mathrm{Ti}$ rotor. $\Lambda$ fter centrifugation, the supernatant was removed and the pellet was resuspended in $\sim 250 \mu \mathrm{l}$ of $5 \mathrm{mM}$ Tris, $\mathrm{pH}$ 7.4.

SDS/Laemmli gel electrophoresis (1.5-mm thick slabs), Coomassie staining of the gels, protein assays, and phospholipid assays were performed as previously described (Papazian et al., 1979). On occasion, the SDS gels were stained by the more sensitive silver staining procedure of Oakley et al. (1980).

Production of antisera and monoclonal antibodies. $\mathrm{BALB} / \mathrm{c}$ mice were immunized by three subcutaneous injections of purified, reconstituted liposomes (10 to 15 $\mu \mathrm{g}$ of protein) as antigen at 3 -week intervals. Antigen was suspended in $50 \mu$ l of $150 \mathrm{mM} \mathrm{NaCl}$ and mixed with $50 \mu \mathrm{l}$ of Freund's complete adjuvant for the first injection and in the same amount of incomplete adjuvant for subsequent injections. Antiserum was obtained by tail bleeding 3 weeks after the last injection and at periodic intervals over the next few months. Additional booster injections were given at 4-week intervals.

For production of monoclonal antibodies, mice were given an intravenous injection of purified, reconstituted liposomes (10 $\mu \mathrm{g}$ of antigen protein) in physiological saline 3 weeks after the third subcutaneous injection. Four days later, spleen cells were harvested and fused with NS1/SP2 mouse myeloma cells (gifts of Colin Barnstable, Harvard Medical School) in the presence of $50 \%$ polyethylene glycol (Baker 1,000 ) as described by Galfre et al. (1977). Hybrid cultures were selected and cloned by repetitive dilution into 96 -well culture plates according to methods adapted from Kohler and Milstein (1975), Barnstable et al. (1978), Brodsky et al. (1979), and St. Groth and Scheidegger (1980). Ascites fluid was obtained from mice approximately 2 weeks after intra- 
peritoneal injection of pristane-primed $\mathrm{BALB} / \mathrm{c}$ mice with 2 to $5 \times 10^{6}$ cloned cells.

Production of antiserum to C94. Purified $\mathrm{Ca}^{2+}$ transport protein $(40 \mu \mathrm{g})$ was subjected to SDS slab gel electrophoresis as described above. The mobility of C94 was measured from corresponding Coomassie-stained gel lanes; 3-mm slices of the unstained gel corresponding to that position were placed into a 5 -ml glass vial. The slices were rinsed three times for $5 \mathrm{~min}$ with phosphate-buffered saline, (PBS) pH 7.4, crushed, and then added to $300 \mu \mathrm{l}$ of PBS. The whole mixture was agitated at room temperature overnight and was centrifuged in a Beckman microfuge at $4^{\circ} \mathrm{C}$ for $5 \mathrm{~min}$. The supernatant $(\sim 200 \mu \mathrm{l})$ was mixed with an equal amount of Freund's adjuvant (complete adjuvant for the first injection and incomplete adjuvant for the subsequent injections) and injected into $\mathrm{BALB} / \mathrm{c}$ mice. The amount of protein in each injection was estimated by the Lowry method to be 5 to $8 \mu \mathrm{g}$.

Radioimmunoassay. Antibody activities from antisera, culture supernatant, and ascites fluid were screened by a solid-phase radioimmunoassay similar to that described by Segal and Klinman (1976). Membrane proteins were diluted with $10 \mathrm{~mm}$ Tris, $\mathrm{pH} 8.3$, to $1 \mathrm{mg} / \mathrm{ml}$ (unless otherwise specified) and were solubilized in the presence of $2 \%$ deoxycholate. The solution was spun in a Beckman $50 \mathrm{Ti}$ rotor at $32,000 \mathrm{rpm}, 4^{\circ} \mathrm{C}$ for $30 \mathrm{~min}$. The supernatant was then diluted four times with PBS, pH 7.4. Fifty microliters of the diluted supernatant were pipetted into each well of an Immulon I (Dynatech) 96-well microtiter plate and were incubated for $1 \mathrm{hr}$ at room temperature. Wells were then washed three times for 5 min with 200 $\mu \mathrm{l}$ of $1 \%$ bovine serum albumin (BSA) in PBS. Fifty microliters of the primary antibody (diluted with $1 \%$ BSA in PBS) were then placed in each well for $1 \mathrm{hr}$, followed by three 5 -min washes with $200 \mu \mathrm{l}$ of $0.1 \% \mathrm{BSA}$ in PBS. Affinity-purified rabbit anti-mouse $\mathrm{IgG}, \mathrm{F}\left(\mathrm{ab}^{\prime}\right)_{2}$ fragment (gift of C. Barnstable) was iodinated using chloramine $\mathrm{T}$ as described by Williams (1977). Fifty microliters of the ${ }^{125}$ I-labeled rabbit antimouse $\mathrm{F}\left(\mathrm{ab}^{\prime}\right)_{2}$ in $1 \%$ BSA, PBS $(\sim 200,000 \mathrm{cpm})$ were injected into each well for $1 \mathrm{hr}$, followed by three 5-min washes with $200 \mu \mathrm{l}$ of $0.1 \%$ BSA in PBS. Each well was then inserted into a $12 \times 75 \mathrm{~mm}$ disposable test tube and was counted in a Beckman 5500 gamma counter.

Competition radioimmunoassay. Membrane fractions were centrifuged at $35,000 \mathrm{rpm}$ in a Beckman 50 Ti rotor for $30 \mathrm{~min}$ and were resuspended with $1 \%$ BSA in PBS at a protein concentration of $20 \mathrm{mg} / \mathrm{ml}$. Serial dilutions of these suspensions were made with $1 \%$ BSA in PBS and were mixed with a fixed concentration of antisera (final dilution 1:400) or ascites fluid containing active monoclonal antibodies (final dilution 1:50,000) against the purified $\mathrm{Ca}^{2+}$ transport protein. The concentrations of antibodies used were roughly twice the $50 \%$ titer point. The mixture of membrane fractions and antibodies were incubated at room temperature for $10 \mathrm{~min}$. Fifty microliters of this mixture were then pipetted into a microtiter well preadsorbed with synaptosomal vesicle protein as described above and were incubated for $1 \mathrm{hr}$ at room temperature. The procedure was in other respects the same as that described above.

Western blots. The electrophoretic gel blotting procedure (Western blot) was an adaptation of the method of
Towbin et al. (1979). Membrane proteins were subjected to SDS/Laemmli gel electrophoresis in $6.5 \%$ polyacrylamide gels. Proteins were then electrophoretically transferred from the gel at $33 \mathrm{~V}$ for $\sim 15 \mathrm{hr}$, using a BioRad Transblot cell onto a $15 \times 15 \mathrm{~cm}$ piece of nitrocellulose paper (Schleicher and Schuell). The electrode buffer was $25 \mathrm{~mm}$ Tris $/ 192 \mathrm{~mm}$ glycine $/ 20 \%(\mathrm{v} / \mathrm{v})$ methanol, $\mathrm{pH}$ 8.3 .

After gel blotting, portions of the nitrocellulose paper were either stained with amido black or incubated overnight with antibodies at $4^{\circ} \mathrm{C}$ in $5 \%$ BSA, $1 \%$ normal rabbit serum (Cappel) in buffer $\mathrm{A}(0.35 \mathrm{M} \mathrm{NaCl}, 0.01 \mathrm{M}$ Tris, $0.1 \mathrm{~mm}$ PMSF, $0.02 \%$ sodium azide, $\mathrm{pH} 7.5$ ). Nonspecific binding of antibodies was reduced by incubation at $40^{\circ} \mathrm{C}$ for $1 \mathrm{hr}$ with $5 \% \mathrm{BSA}$ in buffer A prior to the addition of antibodies. The nitrocellulose sheets were subsequently rinsed three times for $1 \mathrm{~min}$ with $5 \%$ BSA in buffer $\mathrm{A}$ and were then incubated with $22 \mu \mathrm{g} / \mathrm{ml}$ of peroxidase-labeled rabbit anti-mouse IgG (Cappel) in 5\% BSA, buffer A for $1 \mathrm{hr}$ at room temperature while agitated on a Thomas rotator. After rinsing three times for 1 min with $1 \%$ BSA in buffer $\mathrm{A}$, the sheets were incubated under agitation for $1 \mathrm{hr}$ at room temperature with $7 \mu \mathrm{g} / \mathrm{ml}$ of mouse peroxidase-antiperoxidase (Sternberger-Meyer) in 5\% BSA, buffer A. The sheets were then rinsed three times for $5 \mathrm{~min}$ in buffer $\mathrm{A}$ and placed in $0.5 \mathrm{mg} / \mathrm{ml}$ of prefiltered diaminobenzidine (Sigma) and $0.01 \% \mathrm{H}_{2} \mathrm{O}_{2}$ in $0.05 \mathrm{M}$ Tris, $0.85 \mathrm{M} \mathrm{NaCl}, \mathrm{pH} 7.6$. As soon as color developed, the sheets were rinsed with a large quantity of water and were air dried.

Preparation of membrane fractions. Sarcoplasmic reticulum was prepared from calf shoulder white muscle according to the method of MacLennan (1970). Calf axolemma was prepared by the method of Devries et al. (1978). Calf erythrocyte membranes (ghosts) were produced by direct adaptation of the procedure of Goldin and Rhoden (1978). Human erythrocyte ghosts were prepared according to Jarrett and Penniston (1978).

Immunoprecipitation of the $\mathrm{Ca}^{2+}$ pump. Synaptosomal vesicle membrane proteins were solubilized and reconstituted into liposomes as described above with one modification: the solubilized mixture was dialyzed against $700 \mathrm{mM}$ glycerol, $25 \mathrm{mM} \mathrm{KCl}, 50 \mathrm{~mm}$ Tris, $25 \mathrm{~mm}$ ammonium acetate, $5 \mathrm{mM} 2$-mercaptoethanol, $\mathrm{pH} 7.5$, instcad of the oxalate-containing buffers. The resulting liposomes were subjected to the first linear density gradient procedure as described but in the absence of oxalate in the gradient solutions. The major phospholipid vesicle gradient peak was retained and diluted with this dialysis buffer to $0.1 \mathrm{mg} / \mathrm{ml}$ of protein. Bovine serum albumin was added to a final concentration of $1 \%$.

These liposomes were then incubated in $500-\mu \mathrm{l}$ aliquots for $30 \mathrm{~min}$ at $24^{\circ} \mathrm{C}$ with varying dilutions of ascites fluid produced from positive clones. Staphylococcus aureus membranes containing protein A (insoluble form, Sigma) were prewashed four times with $0.5 \%$ Triton X100 and $1 \%$ BSA in dialysis buffer and three times with $1 \%$ BSA in dialysis buffer (Merisko et al., 1982). Fifty microliters of this prewashed protein A $(25 \% \mathrm{w} / \mathrm{w})$ in dialysis buffer were added to each $500 \mu \mathrm{l}$ of liposome/ ascites fluid mixture and were incubated under gentle agitation for $30 \mathrm{~min}$ at $24^{\circ} \mathrm{C}$ followed by $30 \mathrm{~min}$ at $4^{\circ} \mathrm{C}$. The mixture was then centrifuged in a Beckman micro- 
fuge at $4^{\circ} \mathrm{C}$ for $5 \mathrm{~min}$. Aliquots of the supernatant were then immediately assayed for remaining ${ }^{45} \mathrm{Ca}^{2+}$ transport activity as follows. Five microliters of $0.28 \mathrm{mM}^{45} \mathrm{Ca}^{2+}$ (4 $\times 10^{6} \mathrm{cpm} / \mathrm{nmol}$ ), $55 \mathrm{mM} \mathrm{MgCl} 2$ with or without $20 \mathrm{mM}$ MgATP were added to $50 \mu \mathrm{l}$ of supernatant and were incubated for $2 \mathrm{~min}$ at $37^{\circ} \mathrm{C}$. The transport assay was in other respects identical to the previously described procedure (Papazian et al., 1979).

The identical procedure was employed to immunoprecipitate the $\mathrm{Ca}^{2+}$ pump from the native synaptosomal vesicle fraction, diluted to a protein concentration of 0.1 $\mathrm{mg} / \mathrm{ml}$ in dialysis buffer.

\section{Results}

Purification of the ATP-dependent $\mathrm{Ca}^{2+}$ uptake activity. The transport specific fractionation procedure, used previously for the purification of ATP-dependent $\mathrm{Ca}^{2+}$ uptake activity from rat brain synaptosomal vesicles ( $\mathrm{Pa}$ pazian et al., 1979), was scaled up and applied to the purification of this transport activity from bovine brain. As previously shown in the case of rat brain, the purification of this activity on density gradients after its reconstitution into liposomes depended on the formation of a $\mathrm{Ca}^{2+}$ oxalate precipitate as a result of the ATPdependent pumping of $\mathrm{Ca}^{2+}$ into only those liposomes containing such a pump. The liposomes were first subjected to density gradient centrifugation to separate them from denser, unreconstituted material. When the liposomes were subsequently pre-incubated with ${ }^{45} \mathrm{Ca}^{2+}$ in the presence of $\mathrm{Mg}^{2+}$ and ATP before they were placed on a second density gradient, a peak of ${ }^{45} \mathrm{Ca}^{2+}$ appeared below the main liposome peak after centrifugation (Fig. $1, A$ and $B$ ). As was the case for rat brain (Papazian et al., 1979), the position of this ${ }^{45} \mathrm{Ca}^{2+}$ peak on the gradient corresponds to the position of the major peak of ATPdependent $\mathrm{Ca}^{2+}$ uptake activity (Fig. $1, B$ and $C$ ). As a control, liposomes obtained from the first gradient were pre-incubated with ${ }^{45} \mathrm{Ca}^{2+}$ and $\mathrm{Mg}^{2+}$ in the absence of ATP; as shown, the peaks of ${ }^{45} \mathrm{Ca}^{2+}$ and corresponding ATP-dependent $\mathrm{Ca}^{2+}$ uptake below the main vesicle peak were absent, because the $\mathrm{Ca}^{2+}$ pump activity had not been activated and the density of those liposomes containing a $\mathrm{Ca}^{2+}$ pump was not increased. Based on the enrichment of ATP-dependent $\mathrm{Ca}^{2+}$ uptake in the gradient region corresponding to fractions 7 to 12 of Figure $1 C$, a 60 - to 100 -fold purification is obtained. Typical specific activity values of the purified transport activity were $120 \mathrm{nmol}$ of $\mathrm{Ca}^{2+} / \mathrm{mg}$ of protein $/ \mathrm{min}$ versus 1.7 $\mathrm{nmol}$ of $\mathrm{Ca}^{2+} / \mathrm{mg}$ of protein/min for the unfractionated, reconstituted transport activity. The overall recovery of reconstituted transport activity in this case was $41 \%$. Routinely, 100 to $150 \mu \mathrm{g}$ of protein were recovered by this procedure.

As resolved by SDS gel electrophoresis (Fig. 2), two major protein components of $M_{\mathrm{r}}=\sim 230,000$ and 94,000 (termed $\mathrm{C} 230$ and $\mathrm{C} 94$, respectively) entered this dense region of the second gradient as a result of transport specific fractionation (lane d). Both $\mathrm{C} 230$ and C94 could, on occasion, be resolved as doublet bands. Neither of these components appeared in the dense gradient region when the reconstituted vesicles were pre-incubated in the absence of ATP (lane c). As shown, small amounts

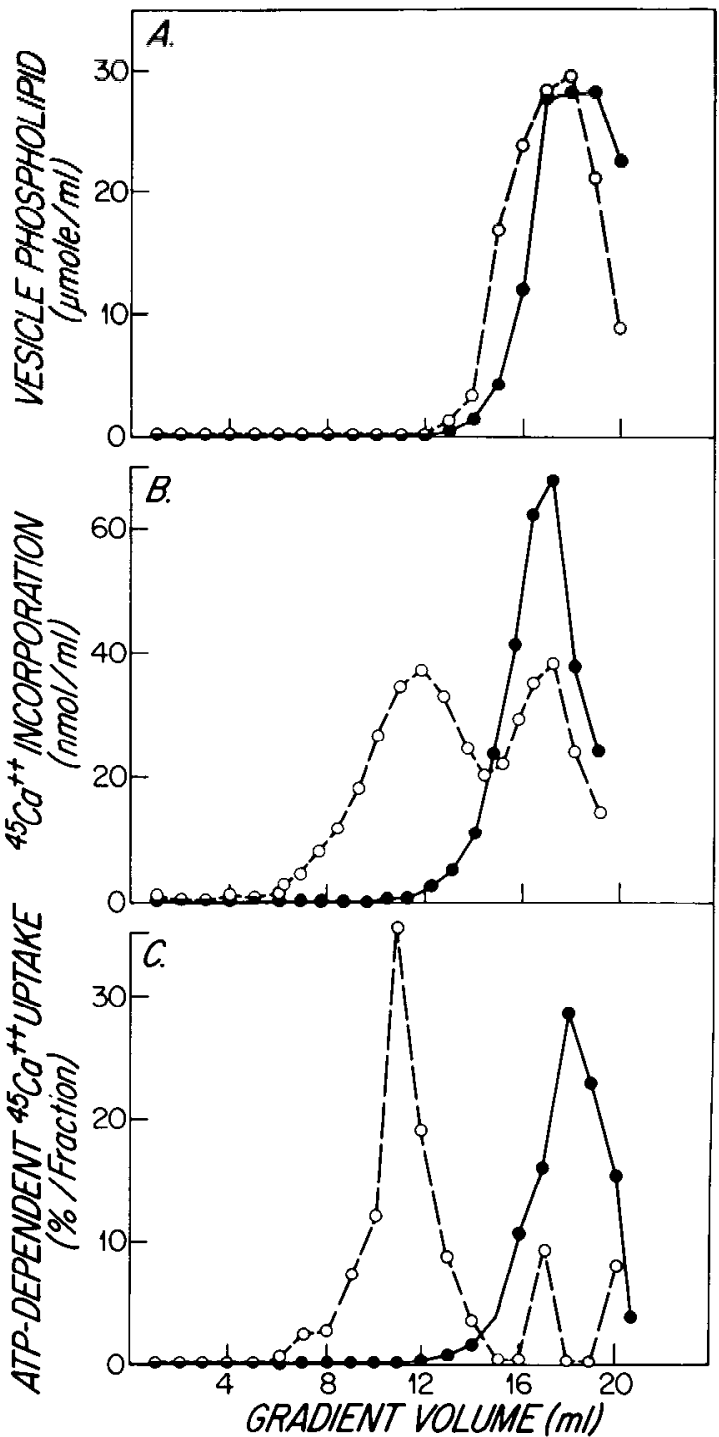

Figure 1. Results of the two-stage gradient purification of the reconstituted $\mathrm{Ca}^{2+}$ transport system from bovine synaptosomal vesicles. Before being placed on the second gradient, the liposome peak obtained from the first gradient was pre-incubated with $\mathrm{Mg}^{2+}$ and $\mathrm{Ca}^{2+}$ in the presence $(O)$ or absence (O) of MgATP. The distribution of ${ }^{45} \mathrm{Ca}$ within vesicles $(B)$ and the ATP-dependent $\mathrm{Ca}^{2+}$ uptake $(C)$, assayed for 2 min at $24^{\circ} \mathrm{C}$, were determined on the second gradient. When the liposomes were pre-incubated in the absence of MgATP prior to being placed on the second gradient, both the ${ }^{45} \mathrm{Ca}$ distribution $(B)$ and the ATP-dependent $\mathrm{Ca}^{2+}$ uptake activity $(C)$ coincided with the major vesicle phospholipid peak $(A)$. Further details are described under "Materials and Melhods."

of lower molecular weight material are found in lane $d$, in addition to C230 and C94.

Properties of antiserum and monoclonal antibodies prepared against the purified, reconstituted transport activity. The bovine synaptosomal $\mathrm{Ca}^{2+}$ uptake activity, purified by transport specific fractionation, was used as the antigen to immunize $\mathrm{BALB} / \mathrm{c}$ mice for the production of antisera and monoclonal antibodies. The activity of the antisera was determined against both native synaptosomal vesicles and the purified $\mathrm{Ca}^{2+}$ transport activity by solid-phase radioimmunoassay (Fig. 3). This assay in- 
volved first attaching the proteins of the membrane fraction to the surface of the wells of microtiter plates, followed by exposure of the insolubilized membrane proteins to the antiserum. Binding of IgG-class antibody was then detected using $\left[{ }^{125} \mathrm{I}\right]$ anti-mouse $\gamma$-globulin $\mathrm{F}\left(\mathrm{ab}^{\prime}{ }_{2}\right)$. In all cases shown here, the maximum amount of antibody binding observed was proportional to the concentration of membrane protein initially employed for insolubilization.

As depicted in Figure 3, the $50 \%$ titer points of the antisera against both native synaptosomal vesicles and the purified transport activity occurred at approximately a 1:1000-fold dilution. The maximum binding of antibody to the synaptosomal vesicles was comparable to the level of binding observed when the purified transport activity was insolubilized to the microtiter dish at a 100 -fold lower concentration than employed for insolubilization of native synaptosomal vesicles. No significant activity



Figure 2. SDS slab gel electrophoresis of the ATP-dependent $\mathrm{Ca}^{2+}$ transport component associated with bovine brain synaptosomal vesicles, after its purification by transport specific fractionation. The $6 \frac{1}{2} \%$ polyacrylamide gel was silver stained. Lane $a$ shows human red blood cell ghosts used as molecular weight standards. Lane $b$ was the protein profile of the unfractionated native bovine synaptosomal vesicles. The last two lanes were results of electrophoresis of material collected from the dense region of the second gradient of the two-stage gradient purification as described in the text. Lanes $c$ and $d$ depict the results when the vesicles were pre-incubated with $\mathrm{Ca}^{2+}$ and $\mathrm{Mg}^{2+}$ in the absence and presence of ATP, respectively.

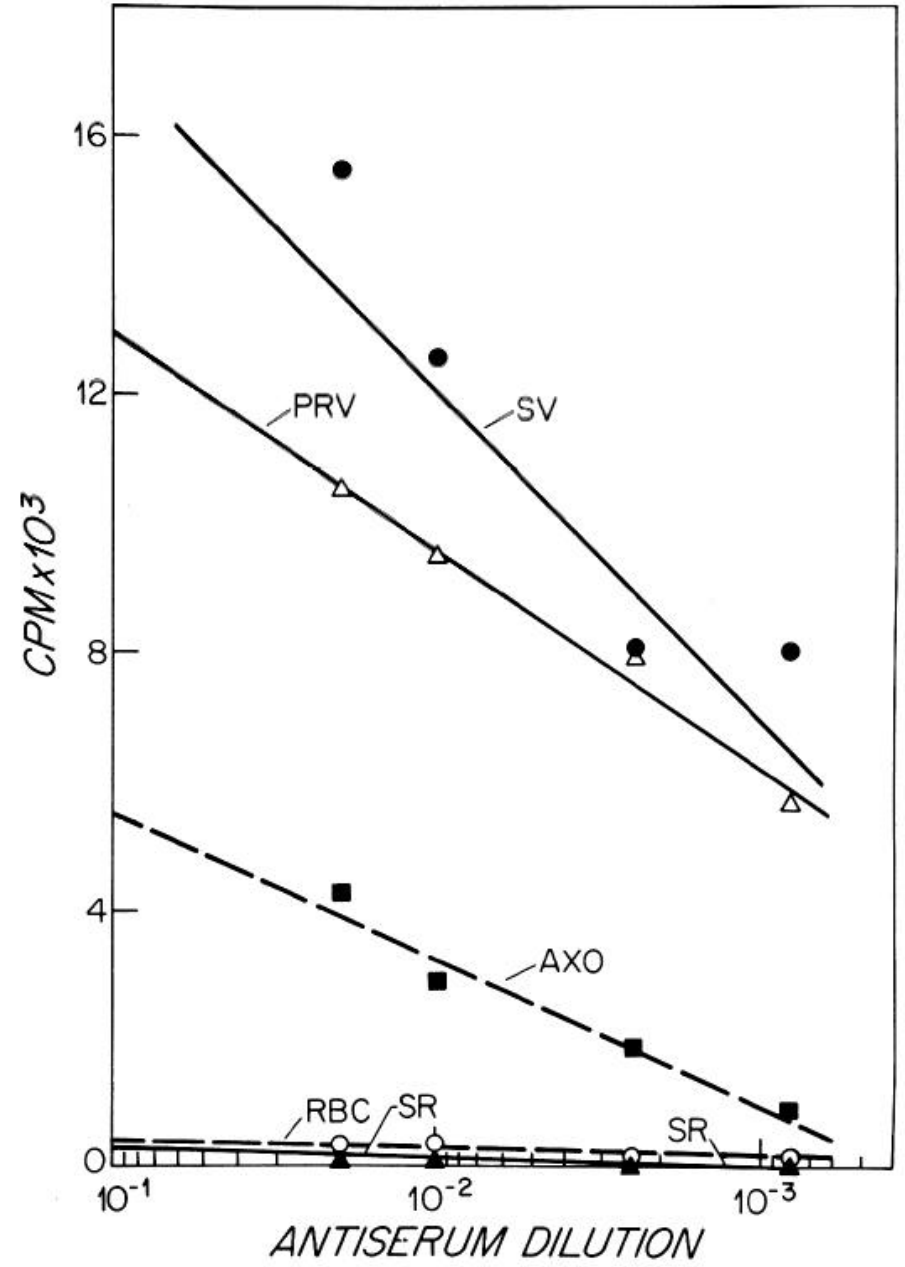

Figure 3. Solid-phase radioimmunoassay showing the antiserum titer against bovine membrane fractions known to contain $\mathrm{Ca}^{2+}$ pumps. Membrane fractions employed were synaptosomal vesicles $(S V)$, erythrocyte ghosts $(R B C)$, sarcoplasmic reticulum $(S R)$, axolemma $(A X O)$ (all from calf), and the ATPdependent $\mathrm{Ca}^{2+}$ transport activity $(P R V)$ purified from synaptosomal vesicles by transport specific fractionation. Each membrane fraction was solubilized with $2 \%$ deoxycholate and was diluted to a protein concentration of $0.25 \mathrm{mg} / \mathrm{ml}$ prior to the application to microtiter wells. PRV was insolubilized at a protein concentration 100 -fold lower than that of SV. The microtiter wells were exposed, in turn, to antiserum of different dilutions, as shown, and to ${ }^{125} \mathrm{I}$-labeled anti-mouse $\mathrm{F}\left(\mathrm{ab}^{\prime}\right)_{2}$.

of the antisera was detected against bovine sarcoplasmic reticulum or bovine erythrocyte membranes. However, substantial cross-reactivity was observed against a bovine membrane fraction enriched in axonal membranes (axolemma).

To determine whether this lack of cross-reactivity against erythrocyte and sarcoplasmic reticulum membranes was due to the inability of the proteins of these membranes to be as effectively insolubilized as synaptosomal proteins, an alternative procedure involving competition for the antibody was also employed. Antiserum was incubated with insolubilized synaptosomal vesicle proteins in the presence of varying concentrations of suspended membranes (Fig. 4). As shown, both synaptosomal vesicles and axonal membranes were effective in 




Figure 4. Competition assay testing the cross-reactivity of antiserum against bovine membrane fractions. Membrane fractions employed were as described in Figure 3. Varying concentrations of membrane fractions were mixed with a 1:400 dilution of antiserum against the purified $\mathrm{Ca}^{2+}$ transport protein. The mixture was then applied to microtiter wells containing insolubilized synaptosomal vesicle proteins (see "Materials and Methods"). Finally, the wells were exposed to ${ }^{125} \mathrm{~T}$-labeled antimouse $\mathrm{F}\left(\mathrm{ab}^{\prime}\right)_{2}$.

competing for the binding of antibodies, but erythyrocyte or sarcoplasmic reticulum membranes were not effective.

Monoclonal antibodies were produced using the spleens of mice immunized as described above. IgGproducing clones were initially selected based on positive reactions against synaptosomal vesicles in the solidphase radioimmunoassay. Out of 88 hydridomas initially screened, five stable cell lines were obtained. As exemplified in Figure 5, $a$ and $b$, all such monoclonal antibodies exhibited basically the same pattern of cross-reactivity as displayed by the antisera: no significant reaction occurred against sarcoplasmic reticulum or erythrocyte membranes, but the antibodies bound to a component of the axonal membrane fraction.

The monoclonal antibodies were further screened for their ability to immunoprecipitate the $\mathrm{Ca}^{2+}$ uptake activity from native synaptosomal vesicles. The immunoprecipitating ability of one of these monoclonal antibodies ("Andy") is depicted in Figure 6. Synaptosomal vesicles were first incubated with the antibody and were subsequently incubated with protein A present in glutaraldehyde-fixed membranes of $S$. aureus. The preparation was subjected to centrifugation at a speed sufficient to pellet any vesicle-associated transport activity that was bound to the larger $S$. aureus membranes but insufficient to pellet significant quantities of unbound synaptosomal vesicles. At a fixed concentration of protein A, an optimum concentration of monoclonal antibody was determined that depleted the synaptosomal vesicles of most of the transport activity (Fig. 6). Higher concentrations of antibody were unable to generate an immunoprecipi- tate; this is presumably attributable to occupancy of most of the protein A immunoglobulin-binding sites by excess antibody that was not bound to the antigenic sites present in the synaptosomal vesicle preparation. Thus, the observed optimum is probably analogous to the "equivalence point" classically observed in standard antiserum precipitation reactions.

This monoclonal antibody was used also to immuno-
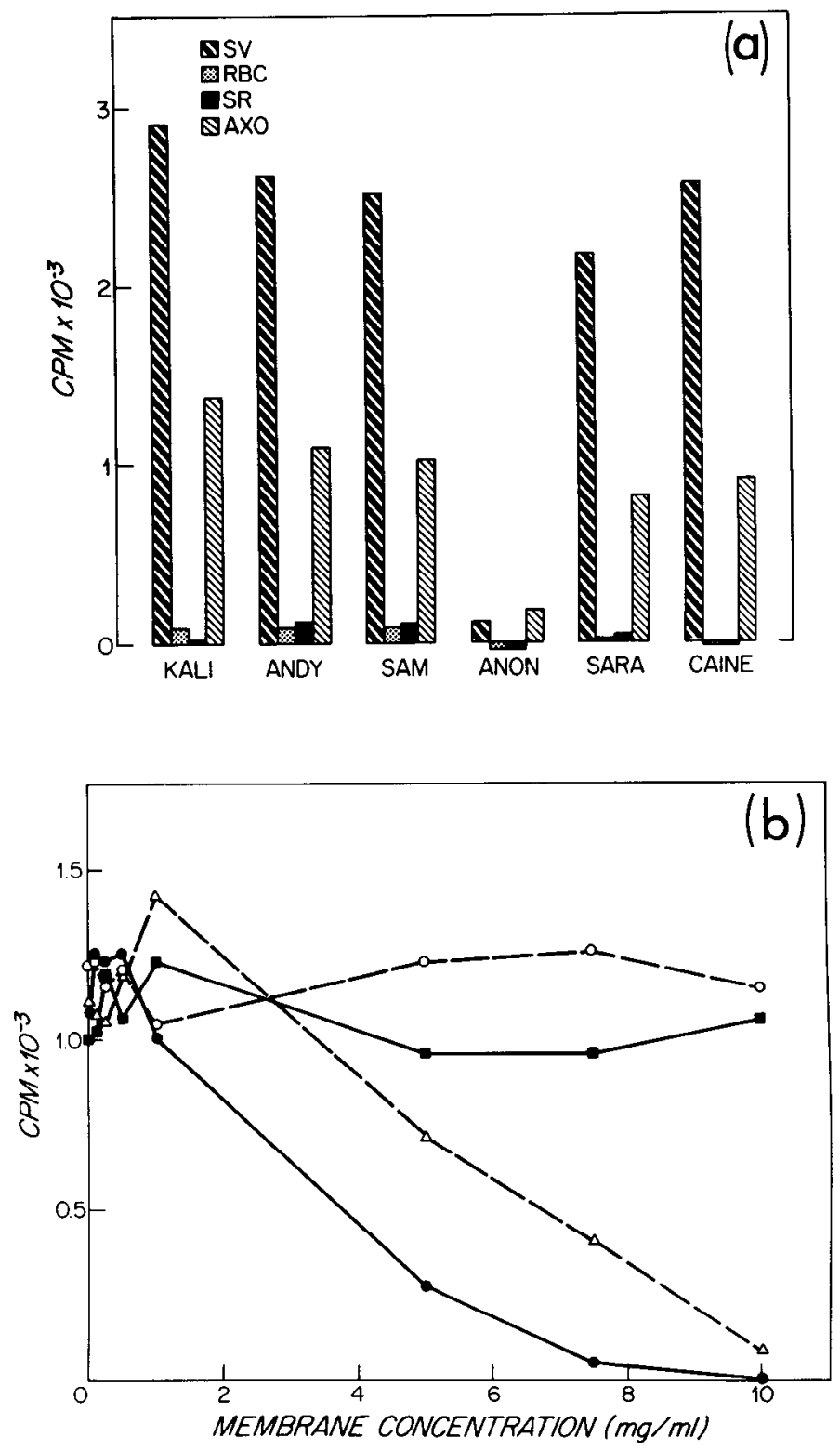

Figure 5. Interaction of monoclonal antibodies with bovine membrane fractions. In $a$, Membrane fractions used were synaptosomal vesicles $(S V)$, erythrocyte ghosts $(R B C)$, sarcoplasmic reticulum $(S R)$, and axolemma $(A X O)$. Each membrane fraction was separately insolubilized to 96 -well microtiter plates and was exposed, in turn, to antibody secreted into the cell culture medium and to ${ }^{125} \mathrm{I}$-labeled anti-mouse $\mathbf{F}\left(\mathrm{ab}^{\prime}\right)_{2}$. Names along the abscissa refer to individual clones. In $b$, the competition assay described in Figure 4 was repeated using a monoclonal antibody (Andy) at a dilution of 1:50,000. Symbols indicate synaptosomal vesicles $(\bullet)$, axolemma $(\triangle)$, erythrocyte ghosts (a), and sarcoplasmic reticulum (O). 


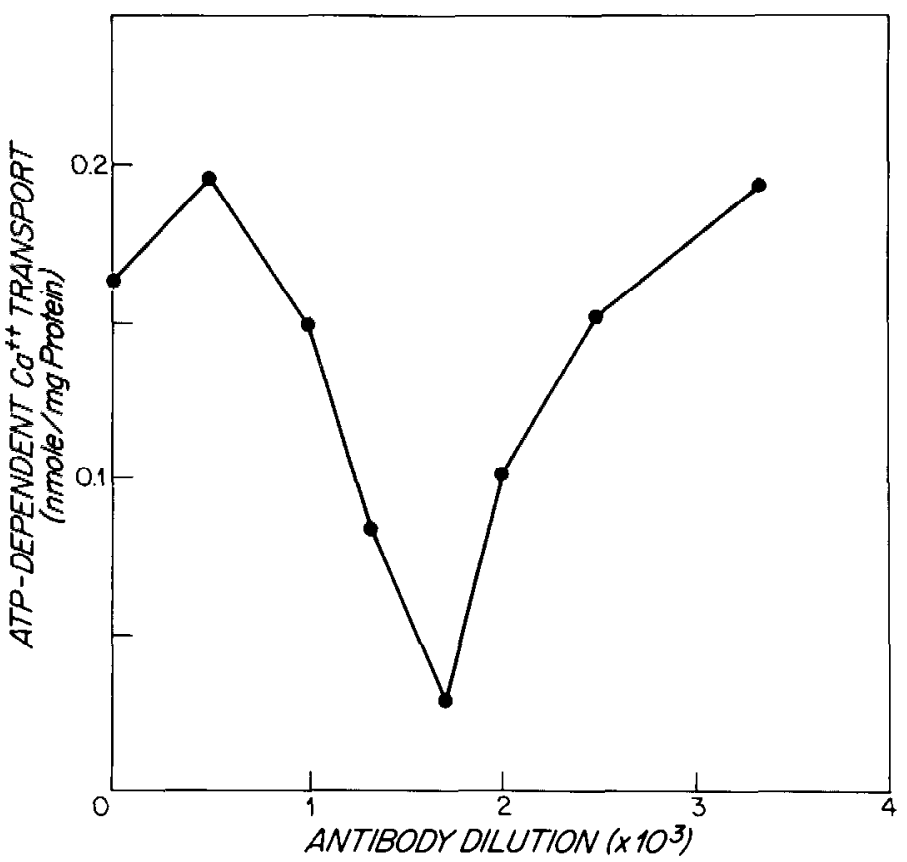

Figure 6. Immunoprecipitation of the ATP-dependent $\mathrm{Ca}^{2+}$ uptake activity from the native bovine synaptosomal vesicle preparation. Synaptosomal vesicles were incubated with dilutions $(1: \infty$ to $1: 300)$ of ascites fluid prepared from a monoclonal antibody ("Andy") specific to the purified $\mathrm{Ca}^{2+}$ transport component. A fixed concentration of membrane-associated protein A was then added. Following additional incubation, the mixture was centrifuged, and the supernatant was assayed for ATPdependent ${ }^{40} \mathrm{Ca}^{2+}$ uptake. As shown, a 1:600 dilution of the antibody yielded the optimal immunoprecipitation of the transport activity.

precipitate the $\mathrm{Ca}^{2+}$ uptake activity after it was solubilized and reconstituted into liposomes (Fig. 7). Approximately half of the reconstituted $\mathrm{Ca}^{2+}$ uptake activity could be removed from the preparation by the antibody in the presence of protein $\mathrm{A}$. In the absence of protein A, the antibody neither inhibited nor immunoprecipitated the activity. As shown, the antibody was effective in causing immunoprecipitation over a broader concentration range than was the case for the $\mathrm{Ca}^{2+}$ uptake activity in native synaptosomal vesicles. To date, "Andy" was the only monoclonal antibody that was shown to be capable of immunoprecipitation.

The Western blot procedure (Towbin et al., 1979) was used to detect the specific interaction of antisera and monoclonal antibodies, with synaptosomal vesicle proteins that were subjected to SDS gel electrophoresis (Fig. 8). As shown, antiserum specifically labels proteins corresponding in molecular weight to $\mathrm{C} 230$ and to $\mathrm{C} 94$; antiserum also strongly labels a family of proteins of lower molecular weight that do not correspond to the two major protein components purified by transport specific fractionation. Conceivably, this lower molecular weight material could be a highly antigenic contaminant in the reconstituted fractionated vesicles used for immunization. In contrast, the five monoclonal antibodies that (as shown in Fig. $5 a$ ) exhibited positive titers against synaptosomal vesicles interact with both $\mathrm{C} 230$ and C94, and they bind to lower molecular weight proteins to a much lesser degree than was the case for antisera. The relative intensity of staining of $\mathrm{C} 230$ is substantially greater than the staining of $\mathrm{C} 94$, although the relative ratios of the two components as purified by transport specific fractionation were similar based on the intensity of silver staining (Fig. 2). On occasion, staining of C94 was barely detectable (e.g., Fig. 9). This result was not due to the inability of C94 to be transferred to the nitrocellulose sheet, because separate experiments (not shown) showed that C94 and C230, purified by transportspecific fractionation, were both impartially transferred to nitrocelullose, and again antibodies labeled C230 more prominently.

The above results indicate that $\mathrm{C} 230$ and C94 are immunologically related. The relationship between C230 and C94 was further explored in the following way. C94 in isolation was obtained by eluting it from SDS gels of the material purified by transport specific fractionation, and it was used as the antigen to prepare an antiserum specific to it. The resulting antiserum to C94 again binds most predominantly to C230 on Western blots (Fig. 8, lane $d$ ). Antiserum prepared to $\mathrm{C} 230$ alone by a similar procedure also reacted predominantly with C230.

The Western blot procedure also reveals that a protein corresponding to C230 is labeled by antiserum in axolemma as well as in synaptosomal vesicle membranes (Fig. 9). No significant labeling of any components of red blood cell ghosts or sarcoplasmic reticulum is ob-

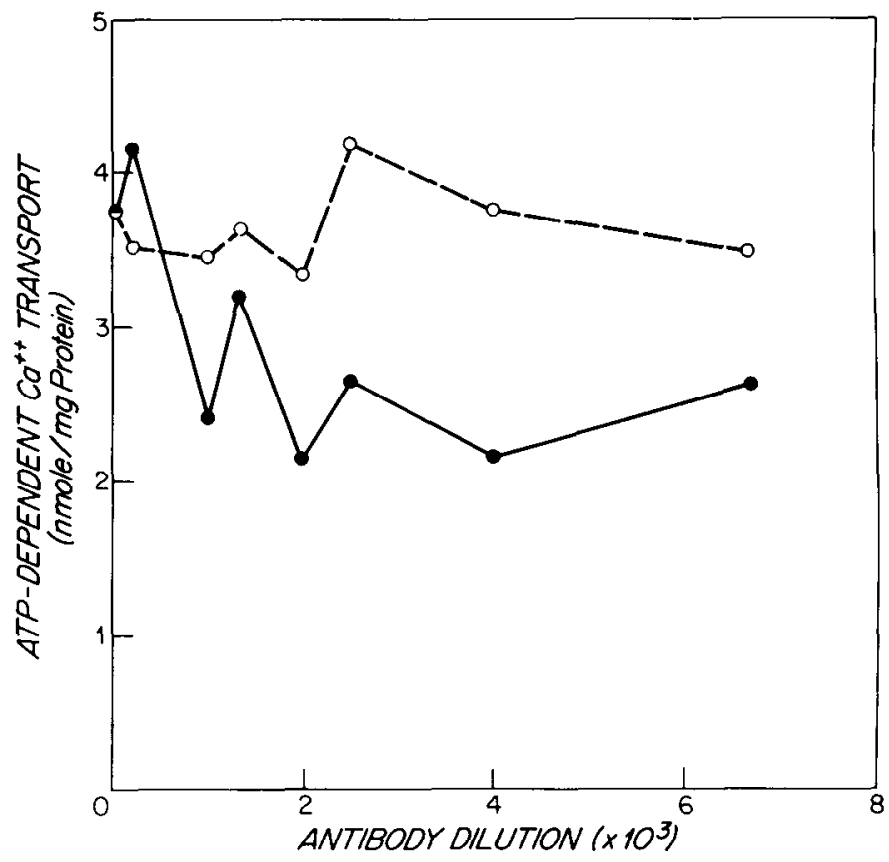

Figure 7. Immunoprecipitation of the ATP-dependent $\mathrm{Ca}^{2+}$ uptake activity after its solubilization and reconstitution into liposomes. Native synaptosomal vesicle membrane proteins were solubilized and reconstituted into asolectin vesicles (see "Materials and Methods"). Unfractionated, reconstituted vesicles were then incubated with varying dilutions of monoclonal antibody in the absence $(O)$ and presence $(O)$ of a fixed concentration of protein A. Following centrifugation, the supernatant was assayed for ATP-dependent $\mathrm{Ca}^{2+}$ uptake activity. As shown, antibody in the absence of protein A neither immunoprecipitated nor inhibited the transport activity. 


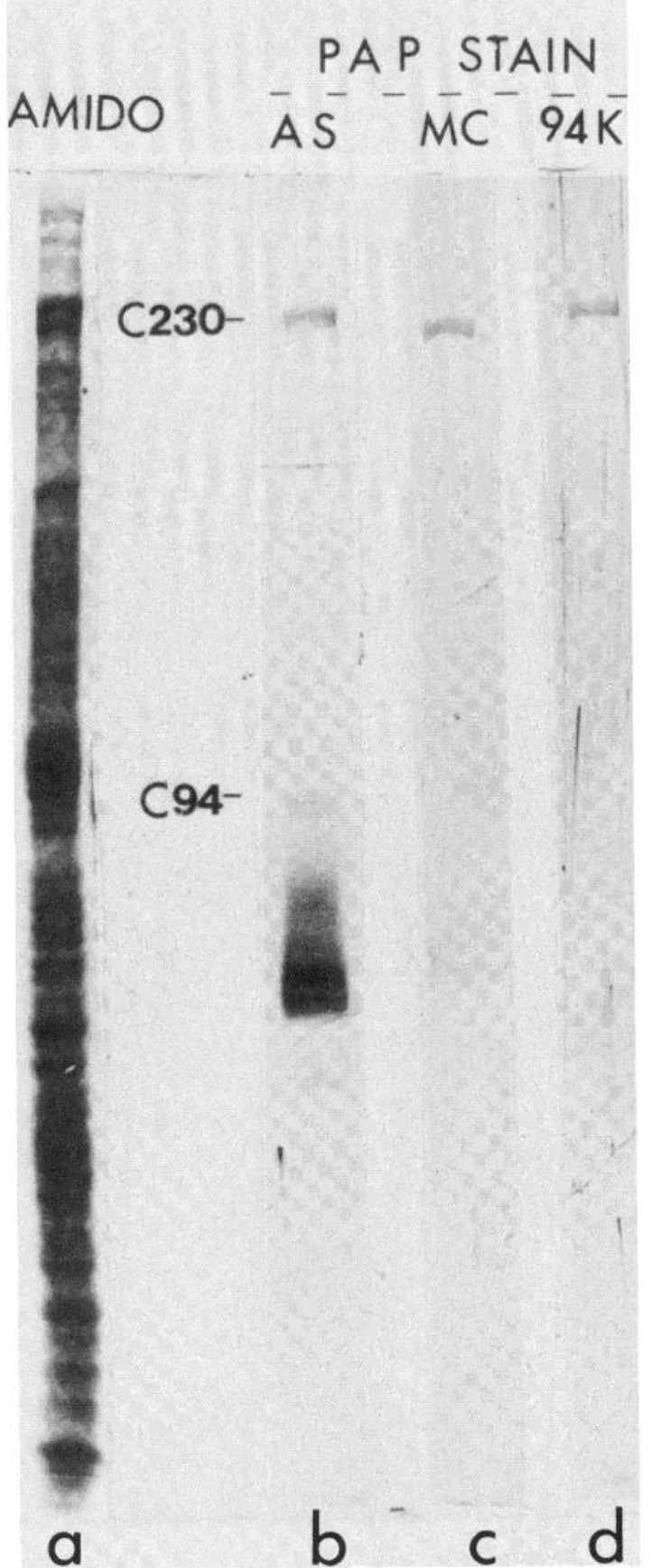

Figure 8. Specific interaction of antiserum and monoclonal antibodies with native synaptosomal vesicle membrane proteins as detected by the Western blot procedure. C230 and C94 indicate the corresponding positions in SDS gels of the two major polypeptides purified from the bovine synaptosomal vesicles. Lane $a$ shows an amido black-stained protein profile of crude synaptosomal vesicle proteins after they were electrophoretically transferred to the nitrocellulose sheet. The other three lanes show specific binding of antibodies as detected by the peroxidase-antiperoxidase staining procedure (PAP $S T A I N)$. Lane $b$ results from binding of mouse antiserum raised against the purified, reconstituted ATP-dependent $\mathrm{Ca}^{2+}$ transport component. Lane $c$ depicts binding of the monoclonal antibody ("Andy") which immunoprecipitated $\mathrm{Ca}^{2+}$ transport activity (Fig. 6 and 7). Lane $d$ resulted from mouse antiserum prepared against C94 alone (see "Materials and Methods"). served. This correlates well with the cross-reactivity data obtained from the solid-phase radioimmunoassay. Monoclonal antibodies exhibit similar ability to label a $M_{\mathrm{r}}=$ 230,000 component in axolemma on Western blots, and they exhibit no labeling of red cell ghosts or sarcoplasmic reticulum (not shown).

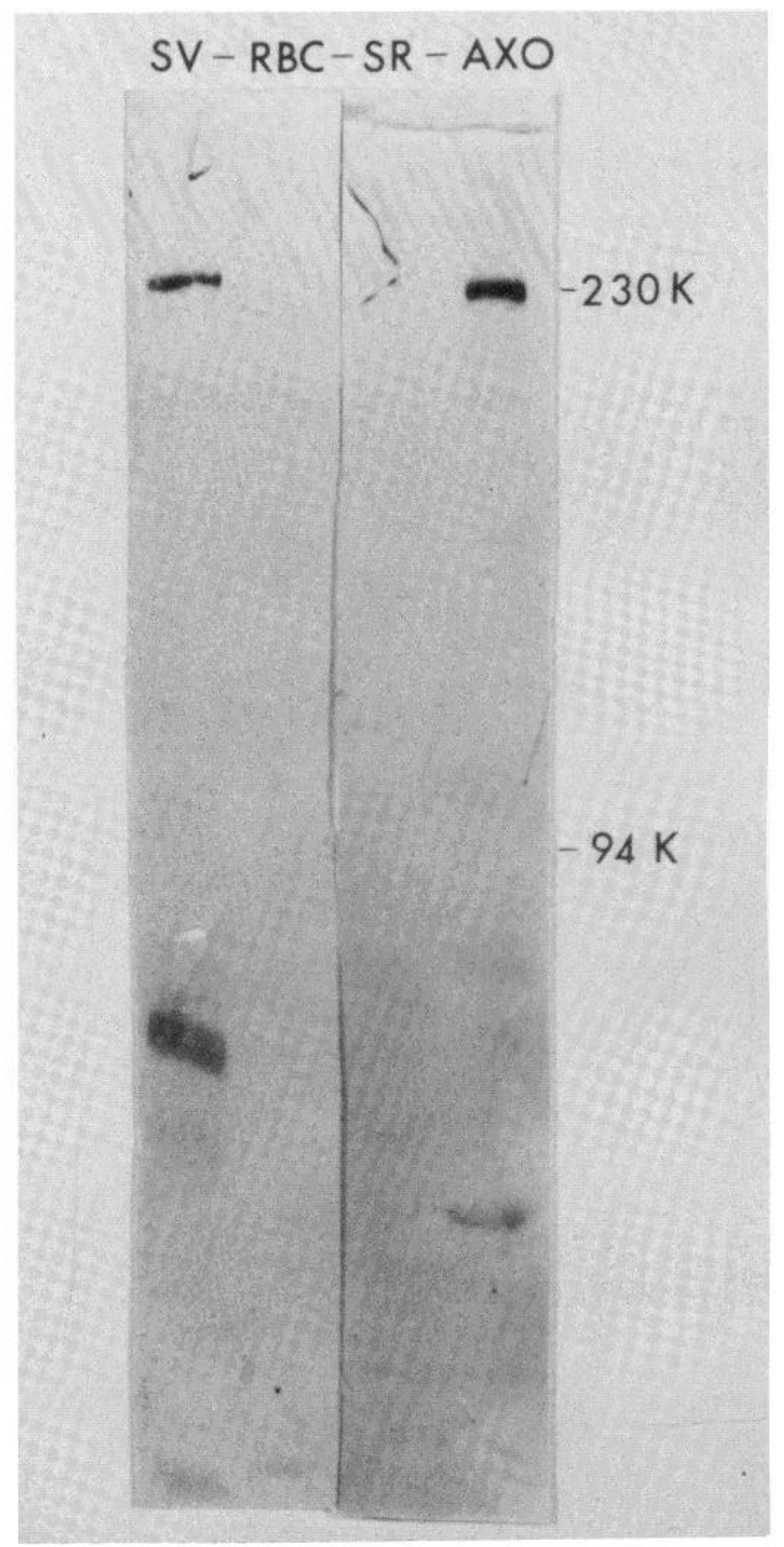

Figure 9. Specific interaction of whole antisera with bovine membrane fractions as detected by the Western blot procedure. Membrane fractions used were synaptosomal vesicles $(S V)$, erythrocyte ghosts $(R B C)$, sarcoplasmic reticulum $(S R)$, and axolemma $(A X O) .230 \mathrm{~K}$ and $94 \mathrm{~K}$ denote the positions of the two major protein components purified from synaptosomal vesicles. 


\section{Discussion}

The molecular identity of the synaptosomal $\mathrm{Ca}^{2+}$ pump. The principal conclusions from these studies relate to the molecular identity of the ATP-dependent $\mathrm{Ca}^{2+}$ uptake activity derived from bovine brain synaptosomal vesicles. Two polypeptides (C230 and C94) are substantially purified by transport specific fractionation of reconstituted synaptosomal vesicle membrane proteins. The fact that their purification depends on the energization of the reconstituted $\mathrm{Ca}^{2+}$ pump by ATP to produce an intravesicular calcium oxalate precipitate suggests that these two polypeptides are components of the $\mathrm{Ca}^{2+}$ uptake activity. However, a question that must in general be resolved when evaluating the results of protein purification procedures is whether the major identifiable proteins are contaminants; the proteins responsible for the function measured could be minor components that are not readily detectable on SDS gels or by other analytical techniques.

Several features of the results reported here argue that at least one if not both polypeplides must be responsible for $\mathrm{Ca}^{2+}$ uptake. First, the specific activity of $\mathrm{Ca}^{2+}$ uptake of the purified, reconstituted $\mathrm{Ca}^{2+}$ pump is comparable to the $\mathrm{Ca}^{2+}$ uptake activity observed under similar conditions by the reconstituted $\mathrm{Ca}^{2+}$ pumps of sarcoplasmic reticulum (Racker and Eytan, 1975) and (corrected for an approximately 4-fold higher activity of the preparation at $37^{\circ} \mathrm{C}$ versus $23^{\circ} \mathrm{C}$ ) human erythrocyte (Niggli et al., 1981). This argues that the protein responsible for $\mathrm{Ca}^{2+}$ uptake in synaptosomal vesicles is if it is mechanistically similar to the above $\mathrm{Ca}^{2+}$ pumps-a major rather than a minor component of the preparation purified by transport specific fractionation. Second, the rationale for the purification of the $\mathrm{Ca}^{2+}$ pump by transport specific fractionation entails its reconstitution into small liposomes, so that only one or a few proteins are present in each vesicle, a situation that had previously been demonstrated to occur for synaptosome-derived $\mathrm{Ca}^{2+}$ pumps (Papazian et al., 1979, 1984) as well as in other systems (Goldin, 1977; Skriver et al., 1980). Thus, those liposomes whose density is increased by ATP-dependent $\mathrm{Ca}^{2+}$ oxalate loading should have the $\mathrm{Ca}^{2+}$ pump as a major (if not the preponderant) protein component. Finally, monoclonal antibodies prepared against the purified $\mathrm{Ca}^{2+}$ transporter interact with C230 and C94 with a high degree of specificity in Western blots and are capable of immunoprecipitating the $\mathrm{Ca}^{2+}$ transport activity from crude synaptosomal proteins after their solubilization and reconstitution.

An additional line of evidence regarding the molecular identity of the $\mathrm{Ca}^{2+}$ pump is the preliminary observation that a protein corresponding in molecular weight to C94 is the major $\gamma-\left[{ }^{32} \mathrm{P}\right] \mathrm{ATP}$-phosphorylatable protein of bovine brain synaptosomal vesicles (Goldin et al., 1983). The phosphorylated intermediate is hydroxylamine-sensitive, a characteristic of the acyl phosphate bonds of the phosphorylated intermediates of other $\mathrm{Ca}^{2+}$ transport ATPases (Makinose, 1969; Papazian et al., 1984).

Both C94 and C230 occasionally appear as doublet bands on SDS gels. The appearance of these doublets could be due to limited protenlysis of these polypeptides; alternatively, there could be multiple molecular forms of $\mathrm{C} 94$ and/or C230 in vivo. It should be noted that there are multiple molecular forms of the $\left(\mathrm{Na}^{+}, \mathrm{K}^{+}\right)$-ATPase in brain that are resolvable by SDS gel electrophoresis and that differ in their sensitivity to cardiac glycosides (Sweadner, 1979).

The relationship between $\mathrm{C} 230$ and C94. Monoclonal antibodies prepared against the purified $\mathrm{Ca}^{2+}$ uptake component bind to both C230 and C94 on Western blots, with a relatively high degree of selectivity for C230. Antiserum prepared against C94 in isolation most prominently stains $\mathrm{C} 230$ on Western blots. The simplest explanation for these observations is the hypothesis that $\mathrm{C} 230$ is a dimer of C94. The dimeric form of the protein may more closely resemble its native conformation and, hence, would account for the stronger antigenicity of C230 than C94 on Western blots.

Support for the hypothesis that C230 is a dimer of C94 is entirely indirect but is, nonetheless, suggestive. First, the purified $\left(\mathrm{Ca}^{2+}-\mathrm{Mg}^{2+}\right)$-ATPase from human erythrocyles exhibit, on SDS gels, a $M_{r}-205,000$ polypeptide that co-purifies in variable amount with a phosphorylatable 125,000-dalton polypeptide (Niggli et al., 1979). The $M_{r}$ 205,000 polypeptide comprised $10 \%$ to $50 \%$ of the total protein in the preparation. Based on the fact that both polypeptides are phosphorylated by $\gamma-\left[{ }^{32} \mathrm{P}\right] \mathrm{ATP}$ under similar conditions, they favored the hypothesis that the 205,000 -dalton polypeptide is a dimer of the smaller polypeptide. Second, there is a body of evidence that the functionally active forms of both the $\left(\mathrm{Na}^{+}, \mathrm{K}^{+}\right)$-ATPase (reviewed by Sweadner and Goldin, 1980) and the sarcoplasmic reticulum $\mathrm{Ca}^{++}$-ATPase (Ikemoto, et al., $1981 \mathrm{a}$, b) are, at a minimum, dimeric. Finally, a well documented instance of visualization of an interconvertable dimer/monomer system on SDS gels is the case of the erythrocyte membrane glycoprotein "PAS 1," which was shown to be a dimer of "PAS 2" of erythrocytes (Marton and Garvin, 1973).

The alternative hypotheses that $\mathrm{C} 230$ and $\mathrm{C} 94$ are subunits of a single $\mathrm{Ca}^{2+}$ pump or represent two distinct but structurally homologous $\mathrm{Ca}^{2+}$ pumps that co-purify with one another cannot at present be discounted. It is also conceivable that $\mathrm{C} 94$ is proteolytically derived from $\mathrm{C} 230$.

Tissue specificity of the synaptosomal vesicle $\mathrm{Ca}^{2+}$ pump. It is clear that the $\mathrm{Ca}^{2+}$ pumps of erythrocyte and sarcoplasmic reticulum are distinctly different protein molecules. The results reported here suggest that the synaptosomal vesicle $\mathrm{Ca}^{2+}$ pump can be a third distinct molecule. Neither monoclonal antibodies nor whole antisera to C230 and C94 cross-react significantly with the $\mathrm{Ca}^{2+}$ pumps or any other components of bovine erythrocyte ghosts or sarcoplasmic reticulum. The lack of cross-reactivity with sarcoplasmic reticulum membranes is particularly striking, because the $\mathrm{Ca}^{2+}$ pump there comprises approximately $50 \%$ of the total membrane protein, in contrast to only about $1 \%$ of the synaptosomal vesicle membrane protein. These results suggest that the synaptosomal vesicle $\mathrm{Ca}^{2+}$ pump has antigenic structural features that are not present in the $\mathrm{Ca}^{2+}$ pumps from 
these non-neuronal sources. The nature and extent of these structural differences remains to be determined. One end of the spectrum is the possibility that large portions of the amino acid sequence of the synaptosomal $\mathrm{Ca}^{2+}$ pump may be unique. The opposite extreme is that the $\mathrm{Ca}^{2+}$ pump could be homologous in amino acid sequence to either the erythrocyte or sarcoplasmic reticulum species, and the antigenic differences are attributable to post-translational modification such as glycosylation.

The substantial cross-reactivity of the antisera and monoclonal antibodies with axolemma membranes may be attributable to the well documented existence of a $\mathrm{Ca}^{2+}$ pump in nerve axons (DiPolo, 1978). This molecule could be identical to the pump associated with synaptosomal vesicles.

The relationship between the synaptic plasma membrane and the synaptosomal vesicles $\mathrm{Ca}^{2+}$ pumps. As reported previously (Papazian et al., 1979), the application of transport specific fractionation to the ATP-dependent $\mathrm{Ca}^{2+}$ uptake activity of rat rather than bovine brain synaptosomal vesicles purifies, in addition to components corresponding to $\mathrm{C} 230$ and $\mathrm{C} 94$, a third minor polypeptide of molecular weight 140,000 . As recently documented (Hakim et al., 1982; Papazian et al., 1982, 1984), synaptic plasmic membranes contains a calmodulin-sensitive $\mathrm{Ca}^{2+}$ pump that has been purified by a procedure that includes calmodulin affinity chromatography. The purified protein, of $M_{\mathrm{r}}-140,000$, cross-reacted with antibodies to the erythrocyte $\left(\mathrm{Ca}^{2+}\right)$-ATPase. We feel it is likely that the $M_{\mathrm{r}}-140,000$ component initially observed in the rat brain synaptosomal vesicle fraction is this synaptic plasma membrane-associated $\mathrm{Ca}^{2+}$ pump. Since it is certain that synaptosomal vesicles and synaptic plasma membrane are, to some extent, cross-contaminated with one another, one cannot conclude that the $M_{\mathrm{r}}-140,000 \mathrm{Ca}^{2+}$ pump is associated with vesicular structures within the nerve terminals as well as with the plasma membrane, the richer source of this pump. Our working hypothesis is that C94 and C230 comprise a nerve tissue-specific, calmodulin-insensitive pump located in vesicles specialized for $\mathrm{Ca}^{2+}$ sequestration. The $M_{\mathrm{r}}-140,000$ protein is a calmodulin-activated pump, similar or identical to that found in the plasma membranes of erythrocyte (Niggli et al., 1979) and muscle (Caroni and Carafoli, 1981). Its function is to actively extrude $\mathrm{Ca}^{2+}$ from the nerve terminal. Immunocytochemical studies now under way should be instrumental in testing this hypothesis.

\section{References}

Barnstable, C. J., W. F. Bodmer, G. Brown, G. Galfre, C. Milstein, A. F. Williams, and A. Ziegler (1978) Production of monoclonal antibodies to group A erythrocytes, HLA and other human cell surface antigens-new tools for genetic analysis. Cell 14: 9-20.

Blaustein, M. P., R. W. Ratzlaff, N. C. Kendrick, and E. S. Schweitzer (1978a) Calcium buffering in presynaptic nerve terminals. I. Evidence for involvement of a non mitochondrial ATP-dependent sequestration mechanism. J. Gen. Physiol. 72: 15-41.
Blaustein, M. P., R. W. Ratzlaff, and E. S. Schwetizer (1978b) Calcium buffering in presynaptic nerve terminals. II. Kinetic properties of the non mitochondrial Ca sequestration mechanism. J. Gen. Physiol. 72: 43-66.

Brodsky, F. M., P. Parham, C. J. Barnstable, M. J. Crumpton, and W. F. Bodmer (1979) Monoclonal antibodies for analysis of the HLA system. Immunol. Rev. 47: 3-61.

Bygrave, F. L. (1977) Mitochondrial $\mathrm{Ca}^{++}$transport. In Current Topics in Bivenergelics, D.R. Sandi, ed., Vol. 6, pp. 259-318, Academic Press, Inc., New York.

Caroni, P., and E. Carafoli, E. (1981) The $\mathrm{Ca}^{2+}$-pumping ATPase of heart sarcolomma: Characterization, calmodulin dependence, and partial purification. J. Biol. Chem. 256: 32633270 .

Devries, G. H., J. Matthieu, M. Beny, R. Chicheportiche, M. Lazdunski, and M. Dolivo (1978) Isolation and partial characterization of rat CNS axolemma-enriched fractions. Brain Res. 147: 339-352.

DiPolo, R. (1978) Ca pump driven by ATP in squid axons. Nature (Lond.) 274: 390-392.

Galfre, G., S. C. Howe, C. Milstein, G. W. Butcher, and J. C. Howard (1977) Antibodies to major histocompatibility antigens produced by hybrid cell lines. Nature 266: 550-552.

Gill, D. I_, E. F. Grollman, and I. D. Kohn (1981) Calcium transport mechanisms in membrane vesicles from guinea pig brain synaptosomes. J. Biol. Chem. 256: 184-192.

Goldin, S. M. (1977) Active transport of sodium and potassium ions by the sodium and potassium ion-activated adenosine triphosphatase of renal medulla: Reconstitution of the purified enzyme into a well-defined in vitro transport system. J. Biol. Chem. 252: 5630-5642.

Goldin, S. M., and V. Rhoden (1978) Reconstitution and "transport specificity fractionation" of the human erythrocyte glucose transport system: A new approach for identification and isolation of membrane transport proteins. J. Biol. Chem. 253: 2575-2583.

Goldin, S. M., S. Y. Chan, D. M. Papazian, E. J. Hess, and H. Rahamimoff (1983) Purification and characterization of ATP-dependent calcium pumps from synaptosomes. Cold Spring Harbor Symp. Quant. Biol. 48: 1-9.

Hakim, G., T. Itano, A. K. Verma, and J. T. Penniston (1982) Purification of the $\mathrm{Ca}^{2+}$ - and $\mathrm{Mg}^{2+}$-requiring ATPase from rat brain synaptic plasma membrane. Biochem. J. 207: 225231.

Ikemoto, N., A. M. Garcia, Y. Kurobe, and T. L. Scott (1981a) Non-equivalent subunits in the calcium pump of sarcoplasmic reticulum. J. Biol. Chem. 256: 8593-8601.

Ikemoto, N., A. Miyao, and Y. Kurobe (1981b) Further evidence for an oligomeric $\mathrm{Ca}^{2+}$ pump by sarcoplasmic reticulum. J. Biol. Chem. 256: 10809-10814.

Jarrett, H. W., and J. T. Penniston (1978) Purification of the $\mathrm{Ca}^{2+}$-stimulated ATPase activator from human erythrocytes: Its membership in the class of $\mathrm{Ca}^{2+}$-binding modulator proteins. J. Biol. Chem. 253: 4676-4682.

Köhler, G., and C. Milstein (1975) Continuous cultures of fused cells secreting antibody of predefined specificity. Nature 256: 495-497.

MacLennan, D. H. (1970) Purification and properties of an adenosine triphosphatase from sarcoplasmic reticulum. J. Biol. Chem. 245: 4508-4518.

Makinose, M. (1969) The phosphorylation of the membranal protein of the sarcoplasmic vesicles during active calcium transport. Eur. J. Biochem. 10: 74-82.

Marton, L. S. G., and J. E. Garvin (1973) Subunit structure of the major human erythrocyte glycoprotein: Depolymerization by heating ghosts with sodium dodecyl sulfate. Biochem. Biophys. Res. Commun. 52: 1457-1462. 
Merisko, E. M., M. G. Farquhar, and G. E. Palade (1982) Coated vesicle isolation by immunoadsorption on Staphylococcus aureus cells. J. Cell Biol. 92: 846-857.

Michaelis, M. L., and E. K. Michaelis (1981) $\mathrm{Ca}^{2+}$ fluxes in resealed synaptic plasma membrane vesicles. Life Sci. 28: 37-45.

Niggli, V., J. T. Penniston, and E. Carafoli (1979) Purification of the $\left(\mathrm{Ca}^{2+}-\mathrm{Mg}^{2+}\right)$ ATPase from human erythrocyte using a calmodulin affinity column. J. Biol. Chem. 254: 9955-9958.

Niggli, V., E. S. Adunyah, J. T. Penniston, and E. Carafoli (1981) Purified $\left(\mathrm{Ca}^{2+}-\mathrm{Mg}^{2+}\right)$-ATPase of the erythrocyte membrane. Reconstitution and effect of calmodulin and phospholipids. J. Biol. Chem. 256: 395-401.

Oakley, B. R., D. R. Kirsch, and N. R. Morris (1980) A simplified ultra-sensitive silver stain for detecting proteins in polyacrylamide gels. Anal. Biochem. 105: 361-363.

Papazian, D., H. Rahamimoff, and S. M. Goldin (1979) Reconstitution and purification by "transport specificity fractionation" of an ATP-dependent calcium transport component from synaptosome-derived vesicles. Proc. Natl. Acad. Sci. U. S. A. 76: 3708-3712.

Papazian, D., H. Rahamimoff, and S. M. Goldin (1982) ATPdependent $\mathrm{Ca}^{2+}$ transport in synaptosomes: Purification of a calmodulin-sensitive $\mathrm{Ca}^{2+}$ pump from synaptic plasma membranes. Soc. Neurosci. Abstr. 8: 692.

Papazian, D. M., H. Rahamimoff, and S. M. Goldin (1984) Partial purification and functional identification of a calmodulin-activated, adenosine $5^{\prime}$-triphosphate-dependent calcium pump from synaptic plasma membranes. J. Neurosci., in press.

Racker, E., and E. Eytan (1975) A coupling factor from sarcoplasmic reticulum required for the translocation of $\mathrm{Ca}^{++}$ions in a reconstituted $\mathrm{Ca}^{++}$ATPase pump. J. Biol. Chem. 250:
7533-7531.

Rahamimoff, H., and E. Abramovitz (1978a) Calcium transport in a vesicular membrane preparation from rat brain synaptosomes. FEBS Lett. 89: 223-226.

Rahamimoff, H., and E. Abramovitz (1978b) $\mathrm{Ca}^{2+}$ transport and ATPase activity of synaptosomal vesicles from rat brain. FEBS Lett. 92: 163-167.

Rahamimoff, H., and R. Spanier (1979) Sodium-dependent calcium uptake in membrane vesicles derived from rat brain synaptosomes. FEBS Lett. 104: 111-114.

Reichardt, L. F., and R. B. Kelly (1983) A molecular description of nerve terminal function. Annu. Rev. Biochem. 52: 871926.

Segal, G. P., and N. R. Klinman (1976) Defining the heterogeneity of anti-tumor responses. J. Immunol. 116: 1539-1546.

Skriver, E., A. B. Mannsbach, and P. L. Jorgensen (1980) Ultrastructure of $\mathrm{Na}, \mathrm{K}$-transport vesicles reconstituted with purified renal Na,K-ATPase. J. Cell Biol. 86: 746-754.

St. Groth, S. F., and D. Scheidegger (1980) Production of monoclonal antibodies: Strategy and tactics. J. Immunol. Methods 35: 1-21.

Sweadner, K. J. (1979) Two molecular forms of $\left(\mathrm{Na}^{+}+\mathrm{K}^{+}\right)$stimulated ATPase in brain: Separation and difference in affinity for strophanthidin. J. Biol. Chem. 254: 6060-6067.

Sweadner, K. J., and S. M. Goldin (1980) Active transport of sodium and potassium ions: Mechanism, function, and regulation. N. Engl. J. Med. 302: 777-783.

Towbin, H., T. Staehelin, and J. Gordon (1979) Electrophoretic transfer of proteins from polyacrylamide gels to nitrocellulose sheets: Procedure and some applications. Proc. Natl. Acad. Sci. U. S. A. 76: 4350-4354.

Williams, A. F. (1977) Differentiation antigents of the lymphocyte cell surface. Contemp. Top. Mol. Immunol. 6: 83-116. 